\title{
Examining Levels and Factors of Speaking Anxiety among EFL Libyan English Undergraduate Students
}

Abdalaziz M. Toubot*, Goh Hock Seng, Azizah binti Atan Abdullah

Department of English, Faculty of Languages and Communication, Universiti Pendidikan Sultan Idris, MALAYSIA

Corresponding Author: Abdalaziz M. Toubot, E-mail: zaherazez2014@gmail.com

\section{ARTICLE INFO}

Article history

Received: February 02, 2017

Accepted: April 11, 2018

Published: September 01, 2018

Volume: 7 Issue: 5

Advance access: July 2018

Conflicts of interest: None

Funding: None

\begin{abstract}
This study aims at investigating EFL the fourth-year students' level of speaking anxiety. Also, the study investigates the main three factors (communication apprehension, fear of negative evaluation and low self-confidence) that contribute to increasing speaking anxiety among EFL learners. The Foreign Language Speaking Anxiety Scale (FLSAS) has been adapted to collect quantitative data and specifically measure speaking anxiety. The sample of this study was 300 fourth-year English department students at three universities in Libya. The findings of this study revealed that students experienced a moderate to high level of EFL speaking anxiety. Additionally, the findings of the study revealed that the low self-confidence factor received the highest average followed by fear of negative evaluation, and communication apprehension factors.
\end{abstract}

Key words: Communication Apprehension, Fear of Negative Evaluation, Fourth-Year English Department Students, Low Self-Confidence, Speaking Anxiety

\section{INTRODUCTION}

Anxious English language students might not be able to successfully pass oral tasks due to their anxiety impeding their ability to fare well (Yan \& Horwitz, 2008). In contrast, relaxed students would perform better because they do not experience the language anxiety impedance (Woodrow, 2006). Foreign language anxiety is a hindrance to successful language learning as it curbs the language learning process E. Horwitz, M. Horwitz, \& Cope, 1986; MacIntyre \& Gardner, 1991; Peng, 2014; Piechurska-Kuciel, 2011).This has a strong impact on speaking skills as it is confirmed by Horwitz et al., 1986. Speaking is the most challenging skill of language learning, and it is one of the most negatively influential affective variables (Marzec-Stawiarska, 2015). It plays an important role in language learning and contributes in reducing learners' oral engagement and performance (Byrne, Flood, \& Shanahan, 2012).

Based on my experience teaching English in Libya to the various levels of studies for more than twelve years, students exhibit different levels of language anxiety. It has been noted that students with low level of anxiety perform better and participate more in the class (Bashosh, Nejad, Rastegar \& Marzban, 2013).

As there are not enough Libyan English lecturers in Libyan universities, the Libyan Ministry of Education usually employ foreign English lecturers and professors from various countries such as India and Philippines on contract basis. Although those foreign lecturers feel satisfied with their students' reading, writing and listening skills, they always complain that the students are not able to convey their ideas orally and not to mention their low proficiency in speaking tasks. According to Hmaid (2014) ESL/EFL learners may be good at reading, writing and listening, but they seem to be poor at speaking skills. The oral skills are ignored in Libyan education and the focus is still on teaching vocabulary and language structure (Najeeb 2013).

Although research on Foreign Language Speaking Anxiety FLSA has been recently increased (Çağatay, 2015; Debreli \& Demirkan, 2015; Qaddomi, 2013; Rashidi, Yamini, \& Shafiei, 2012; Tianjian, 2010; Woodrow, 2006), no study have been conducted in Libyan context. Also, based on the related literature of speaking anxiety no study identified speaking anxiety factors that affect ESL/EFL learners. Therefore, the current study investigates speaking anxiety levels and factors that affect EFL Libyan pre-service teachers.

\section{LITERATURE REVIEW}

\section{Factors and Symptoms of Speaking Anxiety}

Ortega (2014) mentions that foreign language speaking anxiety are made up of various symptoms for example freezing up and be in a confused state despite preparation. Hanna and Gibson (1992) state that public speaking anxiety is exhibited in various ways (i.e. blood pressure, trembled hands, weakness, anxiousness, forgetting the prepared material, and avoid eye contact with the audience).

Several factors contribute to FL speaking anxiety which includes linguistic, psychological, and cultural factors. The 
first factor is low linguistic capabilities. Ellis (2015) mentioned that the learner with inadequate linguistic knowledge (grammar, pronunciation, and lexis) has the tendency to have high anxiety levels. The outcomes of Kayaoglu and Saglamel's interview (2013) with 30 Turkish EFL students showed that linguistic complications (vocabulary, grammar, and pronunciation) amplified their language anxiety. Furthermore, Melouah (2013) examined the sources and levels of 54 Algerian EFL university students' oral performance anxiety, and the study indicated that students experience moderate level of speaking anxiety and resolved that amongst the sources of the said anxiety was low language proficiency. Similarly, utilizing semi-structured interviews, Tanveer (2007) came to a conclusion that speaking anxiety among $20 \mathrm{EFL} / \mathrm{ESL}$ learners was caused by language learning complications. On the other hand, certain studies such as Awan, Azher, Anwar and Naz (2010), Mahmoodzadeh (2012) and Azizifar, Faryadian and Gowhary (2014) indicated that language anxiety influenced EFL students' language achievement. For instance, Awan et al., (2010) discovered that $149 \mathrm{EFL}$ students' language performance was negatively influenced by language anxiety in University of Sargodha. Furthermore, Azizifar et al., (2014) investigated the association between anxiety and English speaking among 80 Iranian EFL learners. Utilizing The Foreign Language Classroom Anxiety Scale (FLCAS) developed by Horwitz et al., (1986) discovered that students experience moderate level of speaking anxiety and if the FLCAS score is high, the English speaking performance was lower. On the other hand, Mahmoodzadeh (2012) specified that knowledge on FL did not essentially lead to lessening in EFL speaking anxiety among 74 Iranian students learning English in an institute. Hence, it is debatable whether speaking anxiety and linguistic competence affect each other.

Psychological factor is another significant factor as there is a close association between personality traits and L2 learning. For instance, extroverts are normally happier to connect with others (Minghe \& Yuan, 2013). Additionally, perfectionists and nervous learners share features for example, higher performance standards and higher level of worries over errors (Gregersen \& Horwitz, 2002). Horwitz et al., (1986) mentioned that communication apprehension (fear of communicating with people), fear of negative assessment (apprehension about others' assessment), and test anxiety (anxiety originating from fear of failure) are contributor to language anxiety. Utilizing qualitative approach Liu (2006) concluded that students experience moderate to high level of speaking anxiety especially when they responded to their teachers or were called on to speak English in class. Liu and Jackson's study (2008) discovered that being afraid of being evaluated, self-assessed and behaving negatively towards English classroom, and dreading failure also contributed to 547 Chinese ESL university students' speaking anxiety. Equally, Ohata (2005) scrutinized language anxiety as observed in 5 Japanese ESL college learners. The detailed interviews revealed that dreading negative assessment and absence of self-confidence instigated the participants' language anxiety. Moreover, Zhiping and Paramasivam's (2013) observations and interviews data showed that dreading neg- ative assessment and apprehensive towards communication instigated anxiety amongst $8 \mathrm{EFL}$ international postgraduate students studying in a Malaysian university.

Along with the learners-related factors, a number of external sources contributors to learners' language anxiety, i.e., lack of teacher support, insensitive personality, dearth of personal attention (Day \& Gu, 2013; Siyli \& Kafes, 2015). Students' anxiety rises when classroom activities are less engaging, lacking in cooperation, unsuitable teacher teaching style, demanding classroom atmosphere, time factors, and unsuitable teaching contents (Zia \& Norrihan, 2015). Exploiting qualitative interviews, Riasati (2011) showed that the grounds for language anxiety as observed by three Iranian EFL adult learners included absence of preparation and implementation of the types of activities. Additionally, Sharif and Ferdous (2012) inspected bases of language anxiety among 60 EFL university students in Bangladesh, and the study specified that the most worrying aspect was connected to teachers. Equally, Subasi (2010) examined the causes of English anxiety among 55 Turkish university learners in oral practice. The study revealed that teachers' manners and teaching procedures were key bases of students' anxiety in English oral practice.

\section{Sources of Foreign Language Anxiety}

According to Scovel (1978), anxiety is a very complicated experience that needs to be perceived as a combination of feelings, state of emotions and personality traits which contributes specific variables that shape anxiety. It is possible for a learner to be more anxious when making a formal speech although he or she has self confidence in his or her own capabilities since he or she has experience handling similar cases whereby the situation is informal. Anxiety depends on how a learner perceives a task or situation and how important it to him or her. Therefore, in order to find out how anxiety might affect a learners' performance, it is vital to focus on the sources of anxiety which are discussed below.

\section{Communication Apprehension}

Past studies such as those by Daly (1997), Tsui (1996) and Leary (2013) utilized different terms to refer to communication apprehension (CA). It has been perceived as reticence, shyness or social anxiety. Anxiety occurs when a person wishes to make a particular impression on the audience but he or she lacks self-confidence on his or her own capabilities. In fact the person might be lacking L2 lexicon, poor pronunciation skills or grammar.

Horwitz (2001) had noted that CA may affect learners when practicing both $\mathrm{L} 1$ and $\mathrm{L} 2$. CA is related directly with language usage. A person who is talkative and open when using their $\mathrm{L} 1$ freely might become reticent and very reluctant to talk while using L2. On the contrary, a person who is not keen to speak L1 might feel more comfortable using L2. While using a foreign language the speaker may feel more distanced from what he or she is saying and have the feeling of someone else speaking (Horwitz, 2001). Such incidents are compared to people who stammer but are able sing or act out scenes very 
well. Hence, the tension felt by a person in a particular communication-oriented situation is the basis for speaking anxiety.

McCroskey (2015) revealed that there is a direct link between lack of confidence in one's skills and reluctance to be involved in interaction with other people as it will directly exposes a person to be evaluated by other people. Thus, anxious learners will underestimate their own abilities although they possess sufficient knowledge they may be unable to speak well because of their own belief that they are incapable of handling it. This anxiety will cause failure to communicate which in turn will create greater level of anxiety. Moreover, McCroskey (2015) has noted that even a person who is generally successful and has a reputable position in a given group is affected by $\mathrm{CA}$ as he or she fears performing very badly and spoiling his or her public image.

According to Aydin (2016) the degree of CA as a source of anxiety is based on EFL learners' levels of proficiency. That is to say, CA may be a main source of anxiety for EFL low proficiency learners while it is not a main source of anxiety for high proficiency learners. Moreover, learners who are affected by $\mathrm{CA}$ will feel more comfortable if they are in a larger group as a larger number of learners involved in an interaction make it possible for anxious learners stay unnoticed at the back of the classroom. Besides, such learners have the inclination to evade interaction and if they are required to give a speech they will opt for short answers using lots of gestures and their speech normally has lots of false starts and hesitation (Philips, 2009). To lessen EFL students' CA, the focus should be on promoting students' level of willingness to communicate (Akdemir, 2016b). Also, Akdemir (2016a) referred that listening is an important component in the communication that should be taken into consideration in measuring students' willingness to communicate in order to alleviate their CA. Therefore, to deeply diagnose the EFL/ESL students' level of CA, he created his new scale called (WTL) in which he focused on listening as a part of communication.

\section{Self-Confidence}

The learning effect is closely related to L2 acquirers' personality factors. Self-confidence is the most significant personality factors. In this case, increased success is reported among those who possess strong self-confidence and positive personal image (Du, 2009). Being adventurous, courage to converse in a foreign language and gaining more are evident among those who possess enough self-confidence. On the other hand, those who lack self-confidence will lose out on practicing their target language as they would be afraid of making mistakes and feeling humiliated (Leong \& Ahmadi, 2017).

Self-confidence is one of the personal factors that highly correlates with anxiety. Judgments and self-evaluation on personal value and worth are some of the traits of self-confidence (Park \& Lee, 2005). A language learner who considers him or her-self inadequate and limited in the target language will negatively affect the person's self-confidence. Conversely, oral performance has a positive relationship with self-confidence (Zhang, 2001). In addition, handling of target language task may be approached by those who are highly anxious leaders in a different manner (Fallah, 2014). Classroom processes are highly correlated to anxiety and, by extension, self-confidence in the L2 classroom (Horwitz et al., 1986; MacIntyre \& Gardner, 1991). A study has shown that there is a negative relationship between oral performance and anxiety among Korean learners, and a positive relationship between oral performance and self-confidence (Park \& Lee, 2005).

\section{Fear of Negative Evaluation}

Fear of negative evaluation (FNE) is related to test anxiety. Nevertheless, it is different from TA because it refers to general evaluation done by other people in any situation while TA refers specifically to a test situation only. An interesting issue to note is those learners who have a high level of fear towards negative evaluation are not always critical towards themselves but once they interact with others they tend to avoid by not participating in the interaction or making a very short and concise contribution (Gardner \& MacIntyre, 1993).

Gregersen and Horwitz (2002) mentioned that FNE influence the behavior of learners directly during communication-oriented situations as they tend to limit their participation in any type of tasks that exposed them to peer or teacher evaluation. The way a learner manage spoken interaction in L2 may be the foundation for other people to develop a general negative view of a particular learner although he or she might be proficient in other language elements or skills. Nevertheless, the problems with oral skills can influence the entire image of a learner among his or her peers. Moreover, should a learner perceive that he or she cannot accomplish the same level of performance in speaking as he or she does in other skills, then the person does not make any effort during speaking-oriented tasks. Lack of practice and avoidance will deprive the learner from developing his or her oral skills. Thus the anxiety problem becomes even greater.

Therefore, anxiety is directly linked to specific situations and it affects learners irrespective of the time and place. This means that it may be temporary or permanent in nature. There are different types and levels of anxiety which can affect a learner's behaviour differently. Thus, further research on the nature and effect of anxiety will enable some insights into the specific factors which can determine development of anxiety. Furthermore, based on Liu (2006) students experience different levels of speaking anxiety according to their academic level. This is to say that English beginners level students experience higher level of speaking anxiety than English advanced level students do. Consequently, students experience speaking anxiety due to their low proficiency in English and/or their fear of learning foreign language. Thus, to measure students' speaking anxiety that stems from their fear of learning a foreign language and not that stems from their low proficiency in English in general, the researcher chose fourth-year English department students to be the sample of the present study.

\section{RESEARCH QUESTIONS}

This study intended to find answers to the following research questions

(1) What are the levels of foreign language speaking anxiety (FLSA) experienced by undergraduate students 
studying at English department in three universities in Libya when speaking in English?

(2) What are the factors cause speaking anxiety among undergraduate students studying at the English department in three universities in Libya?

\section{METHODOLOGY}

\section{Participants}

The current study was conducted during 2016-2017 academic year with participation of (300) EFL fourth-year undergraduate students in three universities in Libya (Al Asmarya University for Islamic Sciences, $\mathrm{Al}$ zaytoonah university and $\mathrm{Al}$ Mergeb University). To avoid the probability of students' speaking anxiety due to their low proficiency in English, the researcher selected English fourth year students. They were more likely to be more familiar with speaking English than any other year students.

\section{Instrument}

\section{Foreign language speaking anxiety scale (FLSAS)}

Foreign Language Speaking Anxiety Scale (FLSAS) is an 18-item questionnaire adopted from Ozturk and Gurbuz (2014) who designed their questionnaire by selecting 18 items from the 33 items of Foreign Language Classroom Anxiety Scale (FLCAS) developed by Horwitz et al., 1986. Ozturk and Gurbuz (2014) explained that they chose the 18 items among 33 items of FLCAS Horwitz's scale which is directly related to foreign language speaking anxiety. The respondents were asked to rate each item on a 5-point Likert scale ranging from ('strongly disagree' to 'strongly agree').

\section{Data Analysis}

The quantitative data is collected through the FLSAS which consists of 18 items. The instrument utilizes the 5-point Likert scale for each item was used to collect data. For the first research question the total score based on the answers to each item given by each respondent on the Likert scale is tabulated. Hence, for each respondent, the total score for the 18 items ranged from 18 to 90 (one point for each item equals 18 points of minimum score in total, whereas five points for each item equals 90 of maximum score). Following Ozturk and Gurbuz (2014) a total score of more than 72 reflects a high level of speaking anxiety, whereas a total score ranging from 54-72 reflects a moderate level of speaking anxiety, and a total score of less than 54 indicated a low level of foreign language speaking anxiety. As for the second research question which pertains to sources and speaking anxiety, the frequencies and percentages of responses to each item were obtained and they form the basis of analysis.

\section{FINDINGS AND DISCUSSION}

\section{Research Question 1}

The first research question of the present study examined the levels of speaking anxiety that the Libyan English undergraduate students experience.

\section{Levels of foreign language speaking anxiety}

Table 1 below shows the levels of speaking anxiety as indicated through the responses obtained in the FLSAS.

The results present in Table 1 reveal that the majority of students experience a moderate level of speaking anxiety. The descriptive results suggest that $48 \%$ of the participants scored 54-72 which indicate a moderate level of speaking anxiety. Also, the percentage of the students who experience a high level of speaking anxiety is considered relatively high with the percentage of $36.33 \%$, whereas, only $15.67 \%$ of them scored less than 54, which indicates a low level of speaking anxiety. In other words, although about half of the students appeared to have a moderate level of speaking anxiety, more than onethird of them experience a high level of speaking anxiety. That is to say; participants experience moderate to high level of speaking anxiety. The reason for this result can be attributed to the teaching method and classroom atmosphere. In a study conducted in the EFL context by Liu (2006), similar results were obtained from a cohort of 547 first year undergraduate students. In another study conducted by Azizifar et al., (2014) in Iranian EFL institute context, the researchers found that participants experience a moderate level of speaking anxiety.

\section{Research Question 2}

Since the speaking anxiety SA questionnaire which is adopted from Ozturk and Gurbus (2014) is not divided into factors, utilizing SPSS, the researcher conducted Exploratory Factor Analysis (EFA) to identify speaking anxiety factors that cause speaking anxiety among undergraduate students studying at the English department in three universities in Libya. The EFA examines whether the 18 items questionnaire are all referring to one factor or more than one factor.

\section{Exploratory factor analysis (EFA)}

The result of EFA indicates that there are three factors among the 16 survey items as the two items are deleted which are 'I get nervous when I don't understand every word my English teacher says' and 'I tremble when I know that I'm going to be called on in English class' in order to obtain better three factors scale. Also, the EFA results show that the Kaiser-Meyer-Olkin Measure of Sampling Adequacy (KMO), which indicates whether the study population was sufficiently large for factor analysis, should be above 0.5 which for this study

Table 1. Respondents' level of speaking anxiety

\begin{tabular}{lcc}
\hline Level of speaking anxiety & $\begin{array}{c}\text { Number of } \\
\text { respondents }\end{array}$ & Percentage \\
\hline $\begin{array}{l}\text { Low level of speaking anxiety } \\
\text { (total score of less than 54) }\end{array}$ & 47 & 15.67 \\
$\begin{array}{l}\text { Moderate level of speaking } \\
\text { anxiety } \\
\text { (total score between 54 and 72) }\end{array}$ & 144 & 48 \\
$\begin{array}{l}\text { High level of speaking anxiety } \\
\text { (total score of more than 72) }\end{array}$ & 109 & 36.33 \\
Total & 300 & 100 \\
\hline
\end{tabular}


is 0.918. According to Field, (2013) the KMO measure can be interpreted as follows: (0.5-0.7 Mediocre, 0.7-0.8 Good, 0.8-0.9 Great, >0.9 Superb). Bartlett's test which is an indication whether the correlations a value of $\mathrm{p} \leq 0.05$ for this test indicated sufficient relationships (Field 2013).

Table 2 shows the result of Bartlett's test where p-value was significant 0.00 which shows satisfactory relationships between the items were sufficiently large for exploratory factor analysis. The determinant of the correlation matrix which indicates whether multicollinearity was not too severe if the determinant is $\geq 0.00001$ (Field 2013). The result of the determinant of the correlation matrix was $0.002>0.00001$ and therefore indicated that there is not too severe multicollinearity.

As a result of EFA, a three factors structure, explaining $55.247 \%$ of total variance, was obtained. The scale's eigenvalue was found to be bigger than 1.00. Figure 1 below shows the scree plot graphic of the scale.

Table 3 shows the result of EFA where the first factor consisted of seven items $(4,7,16,8,11,12$, and 14) according to the items ordered in Ozturk and Gurbaz (2014) SA questionnaire. Item loads of this factor varied between 0.50 and 0.77 . This factor explaining $40.990 \%$ of the total variance forms the 'communication apprehension dimension' of the scale. The second factor consisted of five items $(6,17,18,2$, and 10). Item loads of this factor varied between 0.51 and 0.81 . This factor, explaining $7.831 \%$ of the total variance, forms the 'fear of negative evaluation dimension' of the scale. The third factor consisted of four items $(1,5,9$, and 13$)$. Item loads of this factor varied between 0.58 and 0.77 . This factor explaining $6.426 \%$ of the total variance forms the 'low self-confidence dimension' of the scale.

\section{Reliability}

The reliability test for the SA scale was computed after the EFA for the whole scale and every factor. The Cronbach's Alpha for the SA scale (16 items) is 0.902, whereas the Cronbach's Alpha for the first factor ( 7 items) is 0.823 , the Cronbach's Alpha for the second factor (5 items) is 0.789 , and the Cronbach's Alpha for the third factor (4 items) is 0.738. All these Cronbach's Alpha values are more than accepted value which is according to Sekaran and Bougie (2016) is (0.60).

\section{Factors of speaking anxiety}

The second research question investigates the factors leading to speaking anxiety among the Libyan English fourth-year students. To answer the second question and based on EFA results, the two alternatives of 'strongly agree' and 'agree' are combined to indicate the percentage of students who are agreeable to each item. Then the average of each factor is computed and compared. To facilitate analyses and discussion, it should be noted that the items in the tables below (Table 4, Table 5, Table 6) are sorted in a descending order where the frequencies are listed from highest to the lowest.

\section{Communication Apprehension Factor}

The data obtained from the English fourth-year students' responses clearly shows that all the items about the fac-
Table 2. KMO and Bartlett's test

\begin{tabular}{lc}
\hline KMO and Bartlett's test & \\
\hline Kaiser-Meyer-Olkin measure of sampling & 0.918 \\
adequacy & \\
Bartlett's test of sphericity & 1864.136 \\
Approx. chi-square & 120 \\
Df & 0.000 \\
Sig.
\end{tabular}

Table 3. Item factor loads and variances of each sub-dimension for SA

\begin{tabular}{lccc}
\hline Items & \multicolumn{2}{c}{$\begin{array}{c}\text { Factor loads for sub-dimension of } \\
\text { the SA scale }\end{array}$} \\
\hline 4 & 0.765 & \\
7 & 0.670 & \\
16 & 0.668 & & \\
8 & 0.562 & & \\
11 & 0.541 & & \\
12 & 0.512 & & \\
14 & 0.503 & 0.806 & \\
6 & & 0.727 & \\
17 & & 0.663 & 0.760 \\
18 & & 0.559 & 0.627 \\
2 & & 507 & 0.580 \\
10 & & & 0.571 \\
1 & & & $6.426 \%$ \\
5 & & & \\
9 & & & \\
13 & & & \\
Total variance & $40.990 \%$ & & \\
Total variance $55.247 \%$ & & & \\
\hline
\end{tabular}

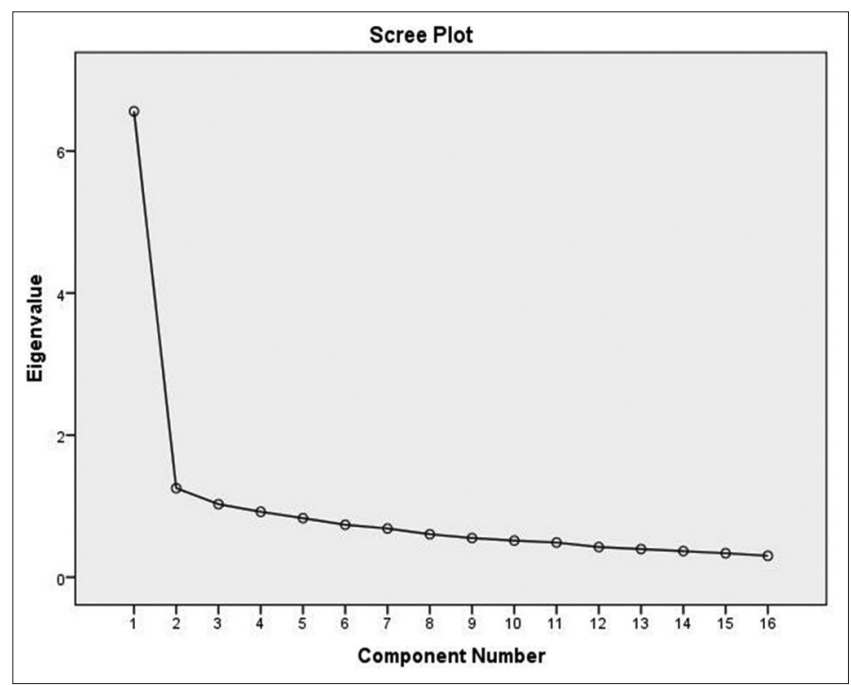

Figure 1. The scree plot for EFA

tor of CA are supported by respondents as can be seen in Table 4 . The items relating to the factor received an aver- 
Table 4. Frequencies and percentages of CA factor items

\begin{tabular}{|c|c|c|c|c|c|c|c|}
\hline No. & Item & SD & D & $\mathbf{N}$ & $\mathbf{A}$ & SA & $\mathbf{A}+\mathbf{S A}$ \\
\hline \multirow[t]{3}{*}{8.} & I get upset when I don't understand what the teacher is correcting & & & & & & \\
\hline & $\mathrm{F}$ & 14 & 40 & 61 & 105 & 80 & 185 \\
\hline & $\%$ & 4.7 & 13.3 & 20.3 & 35 & 26.7 & 61.7 \\
\hline \multirow[t]{3}{*}{11.} & I can feel my heart pounding when I am going to be called on in English classes & & & & & & \\
\hline & $\mathrm{F}$ & 11 & 51 & 86 & 105 & 47 & 152 \\
\hline & $\%$ & 3.7 & 17 & 28.7 & 35 & 15.7 & 50.7 \\
\hline \multirow[t]{3}{*}{16.} & I feel overwhelmed by the number of rules I have to learn to speak English & & & & & & \\
\hline & $\mathrm{F}$ & 33 & 52 & 74 & 111 & 28 & 139 \\
\hline & $\%$ & 11 & 17.3 & 24.7 & 37 & 9.3 & 46.3 \\
\hline \multirow[t]{3}{*}{4.} & I get frightened when I don't understand what the teacher is saying in English & & & & & & \\
\hline & $\mathrm{F}$ & 25 & 55 & 86 & 102 & 32 & 134 \\
\hline & $\%$ & 8.3 & 18.3 & 28.7 & 34 & 10.7 & 44.7 \\
\hline \multirow[t]{3}{*}{7.} & I feel nervous while speaking English with native speakers & & & & & & \\
\hline & $\mathrm{F}$ & 12 & 62 & 93 & 100 & 33 & 133 \\
\hline & $\%$ & 4 & 20.7 & 31 & 33.3 & 11 & 44.3 \\
\hline \multirow[t]{3}{*}{12.} & I always feel that the other students speak English better than I do & & & & & & \\
\hline & $\mathrm{F}$ & 24 & 72 & 76 & 99 & 29 & 128 \\
\hline & $\%$ & 8 & 24 & 25.3 & 33 & 9.7 & 42.7 \\
\hline \multirow[t]{3}{*}{14.} & I get nervous and confused when I am speaking in English classes & & & & & & \\
\hline & $\mathrm{F}$ & 42 & 50 & 93 & 73 & 40 & 113 \\
\hline & $\%$ & 14 & 16.7 & 31 & 24.3 & 13.3 & 37.7 \\
\hline \multicolumn{2}{|c|}{ Average of $\mathrm{SA}+\mathrm{A}$} & \multicolumn{6}{|c|}{140.57} \\
\hline
\end{tabular}

Table 5. Frequencies and percentages of (FNE) items

\begin{tabular}{|c|c|c|c|c|c|c|c|}
\hline No. & Item & SD & D & $\mathbf{N}$ & $\mathbf{A}$ & SA & $\mathbf{A}+\mathbf{S A}$ \\
\hline \multirow[t]{3}{*}{18.} & $\begin{array}{l}\text { I get nervous when the English teacher asks questions which I haven't } \\
\text { prepared in advance }\end{array}$ & & & & & & \\
\hline & $\mathrm{F}$ & 4 & 21 & 39 & 106 & 130 & 236 \\
\hline & $\%$ & 1.3 & 7 & 13 & 35.3 & 43.3 & 78.7 \\
\hline \multirow[t]{3}{*}{2.} & I am afraid of making mistakes in English class & & & & & & \\
\hline & $\mathrm{F}$ & 4 & 24 & 50 & 158 & 64 & 222 \\
\hline & $\%$ & 1.3 & 8 & 16.7 & 52.7 & 21.3 & 74 \\
\hline \multirow[t]{3}{*}{6.} & I get embarrassed to volunteer answers in English classes & & & & & & \\
\hline & $\mathrm{F}$ & 28 & 69 & 73 & 89 & 41 & 130 \\
\hline & $\%$ & 9.3 & 23 & 24.3 & 29.7 & 13.7 & 43.3 \\
\hline \multirow[t]{3}{*}{10.} & I am afraid that my English teacher is ready to correct every mistake I make & & & & & & \\
\hline & $\mathrm{F}$ & 16 & 55 & 100 & 108 & 21 & 129 \\
\hline & $\%$ & 5.3 & 18.3 & 33.3 & 36 & 7 & 43 \\
\hline \multirow[t]{3}{*}{17.} & I am afraid that the other students will laugh at me when I speak English & & & & & & \\
\hline & $\mathrm{F}$ & 43 & 52 & 83 & 83 & 39 & 122 \\
\hline & $\%$ & 14.3 & 17.3 & 27.7 & 27.7 & 13 & 40.7 \\
\hline \multicolumn{2}{|c|}{ Average of $\mathrm{SA}+\mathrm{A}$} & \multicolumn{6}{|c|}{167.8} \\
\hline
\end{tabular}

age frequency of 140.57 among the responses agreeing to the items.

Table 4 shows that more than half of the respondents 61.7 $\%$ feel upset when they do not understand their teachers' corrections item 8 . Based on responses to the third interview question, "what do you do when you do not understand what the teacher is saying?", where $80 \%$ of the interview participants show their preference to ask their colleagues about what they did not understand from their teachers, this result could be attributed to the lack of harmony inside the English 
Table 6. Frequencies and percentages of (LSC) items

\begin{tabular}{|c|c|c|c|c|c|c|c|}
\hline No. & Item & SD & D & $\mathbf{N}$ & $\mathbf{A}$ & SA & $\mathbf{A}+\mathbf{S A}$ \\
\hline \multirow[t]{3}{*}{13.} & I feel very self-conscious about speaking English in front of other students & & & & & & \\
\hline & $\mathrm{F}$ & 14 & 13 & 38 & 102 & 133 & 235 \\
\hline & $\%$ & 4.7 & 4.3 & 12.7 & 34 & 44.3 & 78.3 \\
\hline \multirow[t]{3}{*}{1.} & I am never quite sure of myself when I am speaking in English & & & & & & \\
\hline & $\mathrm{F}$ & 15 & 44 & 56 & 106 & 79 & 185 \\
\hline & $\%$ & 5 & 14.7 & 18.7 & 35.3 & 26.3 & 61.7 \\
\hline \multirow[t]{3}{*}{5.} & I start to panic when I have to speak without preparation in English classes & & & & & & \\
\hline & $\mathrm{F}$ & 17 & 32 & 76 & 112 & 63 & 175 \\
\hline & $\%$ & 5.7 & 10.7 & 25.3 & 37.3 & 21 & 58.3 \\
\hline \multirow[t]{3}{*}{9.} & I don't feel confident when I speak English in classes & & & & & & \\
\hline & $\mathrm{F}$ & 31 & 70 & 69 & 116 & 14 & 130 \\
\hline & $\%$ & 10.3 & 23.3 & 23 & 38.7 & 4.7 & 43.3 \\
\hline \multicolumn{2}{|c|}{ Average of $\mathrm{SA}+\mathrm{A}$} & \multicolumn{6}{|c|}{181.25} \\
\hline
\end{tabular}

classroom between the teacher and his/her students. The lack of harmony could be interpreted as students feel too uncomfortable to ask their teachers about the ambiguities they face, and instead they ask their classmates. Therefore, teachers are responsible for creating a good learning atmosphere inside the classroom. Also, speaking instructors should ensure that their students understand what their mistakes are to avoid them later. This result agrees with Subasi (2010) who referred that teachers' manner and teaching procedures are the main reason for the students' speaking anxiety.

Also, more than the half of the students $50.7 \%$ feel anxious and their heart beating quickly when they are asked to speak English in class item 11. Moreover, the results of this factor indicates that more than one-third of the students experience speaking anxiety due to the number of rules they have to master in order to speak grammatical English, they do not understand what teacher is saying in English, their speaking with native speakers, their feeling of the other students speak English better than they do, and their speaking English in class. This is clearly noticed when the students' responses to items $16,4,7,12$, and 14 with percentages of $46.3 \%, 44.7 \%, 44.3 \%, 42.7 \%$, and $37.7 \%$ respectively. For example, in item 16 students experience speaking anxiety due to their concern about the number of rules they must acquire to speak English. Students' concern about grammar hinders them from speaking English fluently due to their fear of making grammar mistakes. Therefore, speaking teachers should not interrupt their students in communicative activities. Besides, they should inform their students that making mistakes is considered as a step in language learning process. That is to say; speaking teachers should emphasize more on fluency than accuracy. This result goes with Ohata's (2005a) result in which he indicated that students' fear of making mistakes and their low self-confidence increase their language anxiety.

For students' response to item 4 'I get frightened when I don't understand what the teacher is saying in English' supports their response to item 8 'I get upset when I don't understand what the teacher is correcting.' The researcher attributes this result to the teachers' teaching style. Teachers should speak slowly and use simple vocabulary to convey their education message in the way that enables students to understand the context in general at least. Also, teachers should explain to their students that it is not necessary to understand every word rather understand what the whole context is about. Teachers should be flexible to the degree that makes students feel comfortable and free to ask any question and speak in English without any constraints. This result is consistent with Sharif's and Ferdous (2012) study in which they concluded that speaking anxiety is connected to teachers and their teaching method.

\section{Fear of negative evaluation factor}

Table 5 shows that most of the respondents $78.7 \%$ feel nervous when their English teacher asks questions which they have not prepared in advance. The researcher attributes this result to not because the students do not know the correct answer but they do not have the ability to speak the language spontaneously. This lack of ability to speak English without preparation could be accepted for English Department freshman and sophomore students, but it should not be accepted for EFL fourth-year undergraduate students. Also, the researcher claims that the students' inability in communication in English without preparing sentences in advance related additionally to same previous mentioned reason which is lack of communicative practice to their fear of negative evaluation. Therefore, all English department lecturers and not just English-speaking professors should make students communicate in English during the whole class instead of letting them using the Arabic language inside the classroom. Hence, this will increase the students' confidence and lessen their concern of the others negative evaluation. This is supported by Gregersen and Horwitz (2002) who indicated that students' lack of practice and their trend to avoid speaking in English due to their fear of others negative evaluation increase their speaking anxiety and curbs the development of their oral skill. 
Also, the results indicate that the majority of students $74 \%$ feel anxious and afraid due to their concern about the consequences of making mistakes in English class as item 2 shows. This result explains Horwitz's et al., (1986) finding that evaluating anxiety is an anxiety that stems from the feeling of fear from failure that students experience. Items 6, 10 and 17 are supported by more than one-third of the participants with the percentages of $43.35 \%, 43 \%$, and $40.7 \%$ respectively. This result indicates that more than one-third of the students experience speaking anxiety due to their fear of being evaluated by their teachers or their colleagues. For example, the result of item 10 'I am afraid that my English teacher is ready to correct every mistake I make,' support the result of item 2 where $74 \%$ of the students feel afraid of making errors in English class. Also, students' feeling that their peers would laugh at them when they speak English item 17 attributes to their fear of negative evaluation and their lack of self-confidence. This is consistent with Ohata (2005a) who found that FNE that students experience increases students' speaking anxiety.

\section{Low self-confidence factor}

Table 6 shows that most of the respondents $78.3 \%$ are very self- conscious about speaking English in front of other students. The researcher attributes such results to the fact of there is a lack of communication and interaction in English among students inside the classroom. This lack of communication may be due to the teaching method that lecturers use inside the classrooms. Libyan schools use the teacher-centred method in which the teachers are the speakers, and the students are the listeners. Schools and universities do not teach students to use the language rather EFL instructors tend to explain structures and reading texts traditionally. For example, teamwork teaching strategy through which students can interact inside the classroom is not something familiar in Libyan schools. In the group work, students would practice speaking English in small groups and discuss issues which provide them the opportunity to use English language in supporting their views. The students' silent role inside the classroom leads to the lack of supportive atmosphere inside the classroom. Creating a supportive milieu inside the classroom is as important as books and teachers in the teaching and learning process. A supportive environment inside the classroom among the students and between them and their teachers boosts students' self-confidence and then alleviate their anxiety, and this leads to better learning and increases their performance. According to Horwitz et al., (1986); MacIntyre and Gardner, (1991) students' self-confidence highly correlated with their language anxiety. Besides, teachers should use the English language in the classroom. Furthermore, English is a foreign language in Libya, and so it is not used in daily life, and this negatively affects the students' language communication inside the classroom. This is consistent with Zia and Norrihan (2015) who indicated that teachers' teaching method and classroom atmosphere are considered as the main factors for alleviating students' speaking anxiety.

Also, such results showed that students feel anxious and experience speaking anxiety due to their lack of self-confidence while speaking English in class and their speaking without preparation. This is clearly noticed when the participants' response to items 1,5 , and 9 with a percentage $61.7 \%, 58.3 \%$, and $43.3 \%$ respectively. For example, more than the half of the participants $58.3 \%$ supported item 5 'I start to panic when I have to speak without preparation in English classes' which reflects their experience of speaking anxiety because of their speaking without preparation. The result of this item supported the students' response to item 18 in the FNE factor in which $78.7 \%$ of them felt nervous when they are asked to respond to their teacher's questions without prior preparation. The researcher attributes this result to the teachers who do not inform their students about the topic that they will talk about in advance. This is the responsibility of the speaking teachers to psychologically prepare their students before they speak about a certain topic through informing them about the topic. Preparing the topics may help students to lessen and overcome their feeling of anxiety. This goes with what Riasati (2011) indicated that language anxiety that students experience stems from their lack of preparation and implementation for the types of activities.

Table 7 was arranged in ascending order which illustrated that the highest average is LSC factor 181.25 followed by FNE factor with an average of 167.8. The lowest average is CA factor which is 140.57 . This result indicates that the majority of the students 181.25 experience low self-confidence. Also, the result refers that more than the half of the students experience fear of others negative evaluation, and more than one-third of them experience CA. This indicates that speaking anxiety is a serious problem that curbs Libyan English fourth-year students from speaking English.

\section{CONCLUSION}

Since Ozturn and Gurbuz (2014) scale investigates ESL/ EFL students levels of speaking anxiety without examining speaking anxiety factors, this study examines students' speaking anxiety levels as well as identifies speaking anxiety factors. This study found that Libyan EFL fourth-year students generally experience moderate to high level of speaking anxiety. Besides, the study concluded that there are three factors that cause speaking anxiety among EFL Libyan undergraduate students namely communication apprehension, fear of negative evaluation and low self-confidence. The study also showed that the low self-confidence factor has the highest average score of 181.25 followed by fear of negative evaluation factor with average of 167.8 and communication apprehension factor with average of 140.57. The students' level of speaking anxiety is high especially when they speak English without preparation, due to their fear of making mistakes and when they speak English in front of their class-

Table 7. The average of the strongly agree and agree alternatives for the three factors

\begin{tabular}{llc}
\hline No. & Factor & Average \\
\hline 1. & Communication apprehension & 140.57 \\
2. & Fear of negative evaluation & 167.8 \\
3. & Low self-confidence & 181.25 \\
\hline
\end{tabular}


mates. However, Teachers are the key solution in alleviating the students' high level of speaking anxiety.

\section{REFERENCES}

Akdemir, A. S. (2016a). The Development and Validation of Willingness-to-Listen in L2 (WTL) Scale. PASAA Journal - Chulalongkorn University Language Institute, 51(5), 127-154.

Akdemir, A. S. (2016b). Willingness to Communicate (WTC) in L2: An Affective Construct of Language Learning Process. Journal of Graduate School of Social Sciences, 20(3), 389-854.

Awan, R., Azher, M., Anwar, M. N., \& Naz, A. (2010). An investigation of foreign language classroom anxiety and its relationship with students' achievement. Journal of College Teaching \& Learning (TLC),7(11), 33-40. https://doi.org/10.19030/tlc.v7i11.249

Aydin, S. (2009). Test anxiety among foreign language learners: A review of literature. Journal of Language and Linguistic Studies, 5(1), 127-137.

Aydin, S. (2016). A Qualitative Research on Foreign Language Teaching Anxiety. The Qualitative Report, 21(4), 629-642.

Azizifar, A., Faryadian, E., \& Gowhary, H. (2014). The effect of anxiety on Iranian EFL learners speaking skill. Applied and Basic Sciences, 8(10), 1747-1754.

Bashosh, S., Nejad, M. A., Rastegar, M., \& Marzban, A. (2013). The relationship between shyness, foreign language classroom anxiety, willingness to communicate, gender, and EFL proficiency. Theory and Practice in Language Studies,3(11), 2098-2106. https://doi. org/10.4304/tpls.3.11.2098-2106

Byrne, M., Flood, B., \& Shanahan, D. (2012). A qualitative exploration of oral communication apprehension. Accounting Education, 21(6), 565-581. https://doi.org/10. 1080/09639284.2012.725636

Çağatay, S. (2015). Examining EFL students' foreign language speaking anxiety: The case at a Turkish State University. Procedia-Social and Behavioral Sciences, 199, 648-656. https://doi.org/10.1016/j.sbspro.2015.07.594

Daly, J. A. (1997). Avoiding communication: Shyness, reticence, and communication apprehension. University of Michigan: Hampton Press.

Day, C., \& Gu, Q. (2013). Resilient teachers, resilient schools: Building and sustaining quality in testing times. New York, NY: Routledge.

Debreli, E., \&Demirkan, S. (2015). Sources and levels of foreign language speaking anxiety of English as a foreign language university students with regard to language proficiency and gender. International Journal of English Language Education, 4(1), 49-62. https://doi. org/10.5296/ijele.v4i1.8715

Du, X. (2009). The affective filter in second language teaching. Asian Social Science, 5(8), 162-165.

Ellis, R. (2015). Understanding Second Language Acquisition (2nd ed.). Oxford: Oxford University Press.

Fallah, N. (2014). Willingness to communicate in English, communication self-confidence, motivation, shyness and teacher immediacy among Iranian English-major un- dergraduates: A structural equation modeling approach. Learning and Individual Differences, 30, 140-147.

Field, A. (2013). Discovering statistics using IBM SPSS statistics. Los Angeles: Sage.

Gardner, R. C., \& MacIntyre, P. D. (1993). A student's contributions to second-language learning. Part II: Affective variables. Language Teaching, 26(1), 1-11. https://doi. org/10.1017/S0261444800000045

Gregersen, T., \& Horwitz, E. K. (2002). Language learning and perfectionism: Anxious and non-anxious language learners' reactions to their own oral performance. Modern Language Journal, 86(4), 562-570. https://doi. org/10.1111/1540-4781.00161

Hancock, D. R. (2001).Effects of test anxiety and evaluative threat on students' achievement and motivation. Journal of Educational Research, 94(5), 284-290. https://doi. org/10.1080/00220670109598764

Hanna, M. S., \& Gibson, J. W. (1992). Public speaking for personal success $\left(3^{\text {rd }}\right.$ ed.). Dubuque, Iowa: William C. Brown.

Hmaid, Y. (2014). The impact of teaching oral communication strategies on English language learners in Libya. (Unpublished doctoral dissertation). De Montfort University, Leicester.

Horwitz, E. (2001). Language anxiety and achievement. Annual Review of Applied Linguistics, 21, 112-126. https:// doi.org/10.1017/s0267190501000071

Horwitz, E. K., Horwitz, M. B., \& Cope, J. (1986). Foreign language classroom anxiety. Modern Language Journal,70(2), 125-132. https://doi. org/10.1111/j.1540-4781.1986.tb05256.x

Kayaoğlu, M. N., \&Sağlamel, H. (2013).Students' perceptions of language anxiety in speaking classes. Journal of History Culture and Art Research, 2(2), 142-160. https://doi.org/10.7596/taksad.v2i2.245

Leary, M. R. (2013). Social Anxiety, Shyness, and Related Constructs. In John P. Robinson, Phillip R. Shaver, \& L. S. Wrightsman (Eds.), Measures of Personality and Social Psychological Attitudes: (Vol. 1, pp. 161-194). United State of America: Harcourt Brace Jouanovich.

Leong, L.-M., \& Ahmadi, S. M. (2017). An analysis of factors influencing learners' English speaking skill. International Journal of Research in English Education, 2(1), 34-41.

Liu, M. (2006).Anxiety in Chinese EFL students at different proficiency levels. System, 34(3), 301-316. https://doi. org/10.1016/j.system.2006.04.004

Liu, M., \& Jackson, J. (2008).An exploration of Chinese EFL learners' unwillingness to communicate and foreign language anxiety. Modern Language Journal, 92(1), 71-86. https://doi.org/10.1111/j.1540-4781.2008.00687.x

MacIntyre, P. D., \& Gardner, R. C. (1991). Methods and results in the study of anxiety and language learning: A review of the literature. Language Learning, 41(1), 85-117. https://doi.org/10.1111/j.1467-1770.1991.tb00677.x

Mahmoodzadeh, M. (2012). Investigating foreign language speaking anxiety within the EFL learner's interlanguage system: The case of Iranian learners. Journal of Language Teaching and Research, 3(3), 466-476. https:// doi.org/10.4304/j1tr.3.3.466-476 
Marzec-Stawiarska, M. (2015). Investigating foreign language speaking anxiety among advanced learners of English. In M. Pawlak\& E. Waniek-klimczak (Eds.), Issues in Teaching, Learning and Testing Speaking in a Second Language (pp. 103-119). New York: Springer. https:// doi.org/10.1007/978-3-642-38339-7_7

McCroskey, J. C. (2015). Introduction to rhetorical communication $\left(9^{\text {th }}\right.$ ed.). New York, NY: Routledge.

Melouah, A. (2013). Foreign language anxiety in EFL speaking classrooms: A case study of first-year LMD students of English at Saad Dahlab University of Blida, Algeria. Arab World English Journal, 4(1), 64-76.

Minghe, G., \& Yuan, W. (2013). Affective factors in oral English teaching and learning. Higher Education of Social Science, 5(3), 57-61.

Najeeb, S. S. (2013). The business of teaching English as a second language: A Libyan case study. Procedia - Social and Behavioral Sciences, 70, 1243-1253.

Ohata, K. (2005). Language anxiety from the teacher's perspective: Interviews with seven experienced ESL/EFL teachers. Journal of Language and Learning, 3(1), 133-155.

Ortega, L. (2014). Understanding second language acquisition. New York, NY: Routledge.

Öztürk, G., \&Gürbüz, N. (2014).Speaking anxiety among Turkish EFL learners: The case at a state university. Journal of Language and Linguistic Studies, 10(1), 1-17.

Park, H., \& Lee, A. R. (2005). L2 learners' anxiety, self-confidence and oral performance. Paper presented at the Proceedings of the $10^{\text {th }}$ Conference of Pan-Pacific Association of Applied Linguistics, Japan.

Peng, J. E. (2014). Willingness to communicate in the Chinese EFL university classroom: An ecological perspective. Bristol: Multilingual Matters.

Philips, S. U. (2009). Participant structures and communicative competence: Warm springs children in community and classroom. United Kingdom, UK: Wiley-Blackwell.

Piechurska-Kuciel, E. (2011). The relationship between language anxiety and the development of the speaking skill: Results of a longitudinal study. In MirostawPawlak, EwaWaniek-Klimczak, \& J. Majer (Eds.), Second language acquisition: Speaking and instructed foreign language Acquisition (pp. 200-212). Toronto: Multilingual Matters.

Qaddomi, H. (2013). Investigating Al-Quds open university students' EFL learning anxiety. An-Najah Univ. J.Res. (Humanities), 27(7), 1533-1562.

Rashidi, N., Yamini, M., \&Shafiei, E. (2012). Oral communication apprehension and affective factors: Self-esteem and introversion/extroversion. Journal of English Language Teaching and Learning, 3(7), 145-174.

Riasati, M. J. (2011). Language learning anxiety from EFL learners' perspective. Middle-East Journal of Scientific Research, 7(6), 907-914.

Scovel, T. (1978). The effect of affect on foreign language learning: A review of the anxiety research. Language Learning,
28(1), 129-142. https://doi.org/10.1111/j.1467-1770.1978. tb00309.x

Sekaran, U., \& Bougie, R. (2016). Research methods for business: A skill building approach ( $7^{\text {th }}$ ed.). United Kingdom: John Wiley \& Sons.

Sharif, M. Y., \&Ferdous, F. (2012). Sources and suggestions to lower listening comprehension anxiety in the EFL classroom: A case study. English Language Teaching, 5(10), 92-104.

Siyli, N. A., \&Kafes, H. (2015).Overrunning speaking anxiety through audio journals. International Journal of Language Studies, 9(1), 23-40.

Subaş1, G. (2010). What are the main sources of Turkish EFL students' anxiety in oral practice? Turkish Online Journal of Qualitative Inquiry, 1(2), 29-49.

Tanveer, M. (2007). Investigation of the factors that cause language anxiety for ESL/EFL learners in learning speaking skills and the influence it casts on communication in the target language. (Unpublished doctoral dissertation). University of Glasgow, United Kingdom.

Thompson, P. (2004). Researching family and social mobility with two eyes: some experiences of the interaction between qualitative and quantitative data. International Journal of Social Research Methodology, 7(3), 237-257.

Tianjian, W. (2010). Speaking anxiety: "More of a function of personality than language achievement". Chinese Journal of Applied Linguistics, 33(5), 95-109.

Tsui, A. B. (1996). Reticence and anxiety in second language learning. In Kathleen M. Bailey \& D. Nunan (Eds.), Voices from the language classroom (pp. 145-167). New York, NY: Cambridge University.

Woodrow, L. (2006). Anxiety and speaking English as a second language. RELC Journal, 37(3), 308-328. https:// doi.org/10.1177/0033688206071315

Yan, J. X., \& Horwitz, E. K. (2008). Learners' perceptions of how anxiety interacts with personal and instructional factors to influence their achievement in English: A qualitative analysis of EFL learners in China. Language Learning, 58(1), 151-183. https://doi.org/10.1111/ j.1467-9922.2007.00437.x

Young, D. J. (1994). Issues in Language Program Direction. In C. A. Klee (Ed.), Faces in a crowd: The individual learner in multisection courses (pp. 3-46). Boston: Heinle \& Heinle Publishers.

Zhang, L. J. (2001). ESL students' classroom anxiety. Teaching and Learning, 21(2), 51-62.

Zhiping, D., \&Paramasivam, S. (2013). Anxiety of speaking English in class among international students in a Malaysian university. International Journal of Education and Research, 1(11), 1-16.

Zia, Z., \&Norrihan, S. (2015). EFL learners' levels of classroom performance anxieties and their causes in classroom speaking activities in Afghanistan. International Journal of English and Education, 4(1), 239-249. 